\title{
Cadmium contamination of sediments in the water reservoirs in Silesian Upland (southern Poland)
}

\author{
Martyna A. Rzętala ${ }^{1}$
}

Received: 18 October 2015 / Accepted: 8 June 2016 / Published online: 18 June 2016

(C) The Author(s) 2016. This article is published with open access at Springerlink.com

\begin{abstract}
Purpose Cadmium $(\mathrm{Cd})$ is considered a toxic element and its concentrations are relevant to human health and the environment. Therefore, the purpose of the study was to determine the extent to which the bottom sediments of water bodies (artificial lakes and ponds) in the Silesian Upland in southern Poland are contaminated with $\mathrm{Cd}$; an attempt was also made to determine the factors that condition spatial differences in the concentration of this element between individual water bodies in the region.

Materials and methods Measurements of the Cd content in bottom sediments were carried out in 35 water bodies in southern Poland in 2011 and 2012. Depending on the surface area and morphometric characteristics, from two to nine samples representative in terms of sediment thickness were collected in each water body. Cadmium concentrations were determined for $920.25 \mathrm{~g}$ aliquots using the TD-ICP method. Results and discussion Cadmium content in all samples (0.7$580.0 \mathrm{mg} \mathrm{kg}^{-1}$ ) was higher than the natural range of concentrations for this element in the Earth's crust $\left(0.1-0.3 \mathrm{mg} \mathrm{kg}^{-1}\right)$ and the geochemical background for Poland $\left(0.5 \mathrm{mg} \mathrm{kg}^{-1}\right)$ and, with a few exceptions, was also higher than the preindustrial concentration $\left(1.0 \mathrm{mg} \mathrm{kg}^{-1}\right)$ and the regional geochemical background $\left(2.5 \mathrm{mg} \mathrm{kg}^{-1}\right)$. Adopting natural Cd concentrations in the Earth's crust $\left(0.1-0.3 \mathrm{mg} \mathrm{kg}^{-1}\right)$ as the baseline for the geoaccumulation index $\left(\mathrm{I}_{\mathrm{geo}}\right)$, the sediments examined can be classified as extremely and heavily contaminated (and
\end{abstract}

Responsible editor: Nives Ogrinc

Martyna A. Rzętała

martyna.rzetala@us.edu.pl

1 University of Silesia, Faculty of Earth Sciences, Bedzinska 60, 41-200 Sosnowiec, Poland moderately contaminated in a small number of cases). The assessment of sediment quality based on $\mathrm{I}_{\text {geo, }}$, with the regional geochemical background $\left(2.5 \mathrm{mg} \mathrm{kg}^{-1}\right)$ adopted as the baseline, results in non-contaminated and moderately contaminated sediments being dominant with a far smaller number of heavily and extremely contaminated ones.

Conclusions In the case of several water bodies, $\mathrm{Cd}$ concentrations were at record levels that have not been found anywhere else in the world. On the basis of the $\mathrm{I}_{\text {geo }}$, sediments of varying quality were found - from virtually uncontaminated to extremely contaminated. The $\mathrm{I}_{\text {geo }}$ index as an indicator of the quality of bottom sediments is a measure that requires careful interpretation, especially when different concentration levels regarded as natural are used for determining its value.

Keywords Bottom sediments · Cadmium - Environmental pollution $\cdot$ Heavy metal $\cdot$ Lakes $\cdot$ Pollution levels $\cdot$ Silesian Upland · Toxic metals · Trace elements · Water reservoirs

\section{Introduction}

Cadmium $(\mathrm{Cd})$ is classified as a highly toxic heavy metal (Håkanson 1980; Bojakowska and Sokołowska 1998). Its high toxicity poses a threat to the development of flora and fauna as well as to human life and health (Bennet-Chambers et al. 1999). Cadmium toxicity may be exacerbated by the presence of other toxic metals, e.g. zinc (Świderska-Bróż 1993). Cadmium is easily absorbed and accumulates in tissues, and its main sources in our diet are fish and cereal products (Olmedo et al. 2013). Long-term Cd poisoning may lead to damage to the kidneys, liver, testes and prostate. Excessive $\mathrm{Cd}$ exposure may also cause anaemia, high blood pressure, circulation problems, decalcification of bones and muscle atrophy (Kabata-Pendias and Pendias 1993). Owing to its toxic 
properties, $\mathrm{Cd}$ is considered unnecessary for the proper functioning of living organisms.

For these reasons, Cd concentrations in the natural environment are monitored closely. Studies of bottom sediments accumulated in water bodies are of special importance since the concentration of $\mathrm{Cd}$ in these sediments is a good indicator of water and sediment pollution and also of environmental conditions that prevail in the catchment in question (Müller 1979; Håkanson 1980). The monitoring of Cd presence in the environment is especially justified in the case of sediments that are present in water bodies, especially where these are used for various purposes, e.g. irrigation in agriculture and the filling of fish ponds, water supply for households and industry, the extraction of mineral resources and recreation.

Studies of Cd content in the natural environment are mainly required in industrialised and urbanised areas with high population density. Such areas include the Silesian Upland in the central part of southern Poland, where the long-term exploitation of mineral resources and the growth of manufacturing industry together with urbanisation processes have resulted in the transformation of the natural environment on a scale unprecedented in Poland. In areas of historical and contemporary extraction of mineral resources (e.g. coal, lead $(\mathrm{Pb})$ and zinc $(\mathrm{Zn})$ ores, iron $(\mathrm{Fe})$ ores), where $\mathrm{Fe}$ and non-ferrous metal smelting as well as other manufacturing industries developed, degradation of the natural environment has been particularly severe (Fig. 1).

The rationale for conducting studies on the $\mathrm{Cd}$ content in the bottom sediments of water bodies in the Silesian Upland is the insufficient recognition of the scale of environmental pollution caused by this element. To date, the presence of $\mathrm{Cd}$ in the bottom sediments of water bodies has been discussed in the context of limnological studies that only touched upon this subject (Jankowski et al. 2002; Ciszewski et al. 2013; Rzętała et al. 2013; Rzetala et al. 2015; Rzętała 2014, 2015b) and also studies conducted within the framework of geochemical examination of soil and surface formations, water and aquatic sediments (Lis and Pasieczna 1995a, b). In those studies, the value of the regional geochemical background for $\mathrm{Cd}$ in aquatic sediments was determined at $2.5 \mathrm{mg} \mathrm{kg}^{-1}$ (Lis and Pasieczna 1995b). Owing to the specific geological structure of the Silesian Upland and the presence of many mineral resources, especially $\mathrm{Zn}$ and $\mathrm{Pb}$ ores in Triassic formations, it is higher than the geochemical background for $\mathrm{Cd}$ in Polish aquatic sediments, which is $<0.5 \mathrm{mg} \mathrm{kg}^{-1}$, and also than the threshold value for the geochemical background of aquatic sediments in Poland, which was determined at $1.8 \mathrm{mg} \mathrm{kg}^{-1}$ (Lis and Pasieczna 1995a). Similar relationships have been found if the natural $\mathrm{Cd}$ content in Polish soils $\left(<0.5 \mathrm{mg} \mathrm{kg}^{-1}\right)$ are compared to that for soils in the Silesian Upland $\left(1.3 \mathrm{mg} \mathrm{kg}^{-1}\right)$, while the geochemical background for $\mathrm{Cd}$ in surface waters in Poland as a whole and on the Silesian Upland is the same, at $<3.0 \mu \mathrm{g} \mathrm{dm}^{-3}$ (Lis and Pasieczna 1995a, b).
The purpose of the study was to determine the extent to which the bottom sediments of water bodies in the Silesian Upland in southern Poland are contaminated with $\mathrm{Cd}$; an attempt was also made to determine the factors that condition spatial differences in the concentration of this element between individual water bodies in the region.

\section{Materials and methods}

The emergence of several thousand (usually small) bodies of water in the Silesian Upland was related to economic development (Rzętała and Jaguś 2012). Natural bodies of water (lakes) are virtually absent in the study area; this is a consequence of, inter alia, the progressing karstification of the substrate in part of the study area, its old-glacial relief and human impact. Anthropogenic basins filled with water dominate this area so much that the Silesian Upland, together with parts of adjacent regions, is referred to as the Upper Silesian Anthropogenic Lake District, which formed in recent decades (Rzętała and Jaguś 2012).

Artificial water bodies serve as sedimentary basins where bottom sediments are formed in which pollutants accumulate. Bottom sediments can be considered a good indicator of environmental conditions and processes that take part in the watershed and in close vicinity of water bodies (Tylmann 2004; Fajer et al. 2012; Szymczyk 2012; Rzętała et al. 2013).

Measurements of $\mathrm{Cd}$ content in bottom sediments were carried out in 2011 and 2012 in 35 water bodies in southern Poland (Fig. 2). The water bodies selected for study are 60 to 70 years old on average and have varying origins: flooded mineral workings, reservoirs impounded by dams and embankments, water bodies in subsidence basin and water bodies with multiple origins. Flooded mineral workings prevail (Fig. 2 (1-31)), with some basins impounded by small dams (Fig. $2(1,2,15,18$ and 32)) or reshaped by subsidence processes (Fig. 2 (27-31)). The remaining impoundments and levee ponds formed due to the slight increase in the water level caused by the presence of dams or levees (Fig. 2 (32-35)). In most cases, these bodies of water are small in terms of their area and retention capacities (Table 1). The surface areas of the water bodies tested range from 0.9 to 561 ha with an arithmetic mean of 49.9 ha, a median equal to 9.0 ha (first quartile 2.9 ha, third quartile 36.7 ha) and a standard deviation of $106.8 \mathrm{ha}$. The amount of water they hold ranges from 6.0 to $94,000 \mathrm{dam}^{3}$; other statistical characteristics concerning the retention capacities of the water bodies in question are as follows: $4597 \mathrm{dam}^{3}$ (arithmetic mean), $202 \mathrm{dam}^{3}$ (median), $57.0 \mathrm{dam}^{3}$ (first quartile), $797 \mathrm{dam}^{3}$ (second quartile) and $16,509 \mathrm{dam}^{3}$ (standard deviation). They also vary in terms of their water quality (Table 1), which is indirectly evidenced by the variability in specific electrolytic conductivity (183.0 

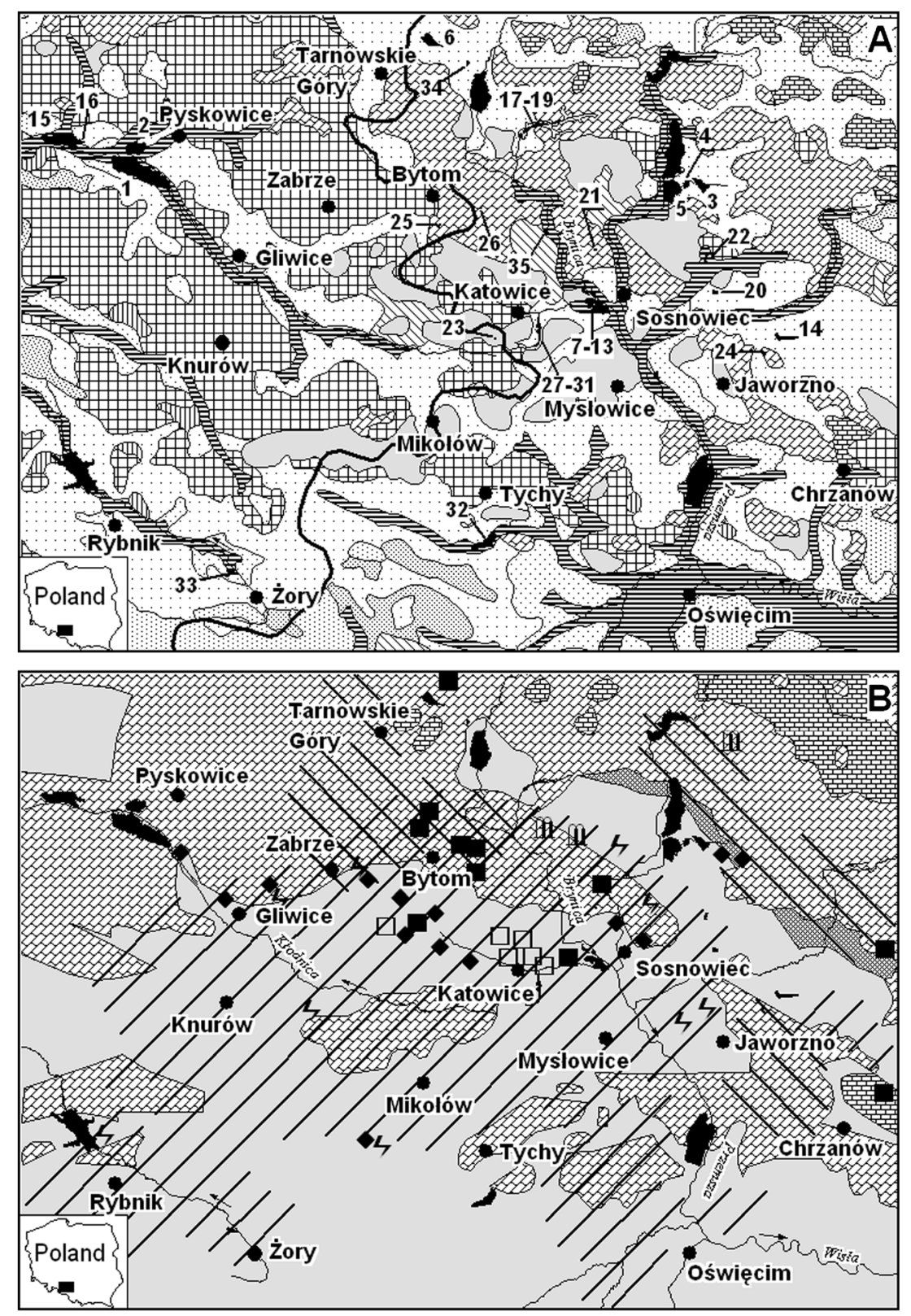

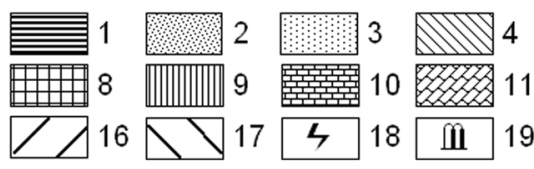

Fig. 1 The distribution of surface formations (a) and the geological structure of the substrate (b) on the Silesian Upland and major mineral resource deposits, their mining and processing (after Lis and Pasieczna 1995b; PGI 2006; simplified and supplemented): 1—sands, gravels, alluvial soils, peat and silts (Holocene); 2 - eolian sands, locally in dunes (Quaternary); 3-loesses, sandy loesses and loess-like dusts (Quaternary); 4 - clays, sands and clays with gruss, solifluctive-deluvial (Pleistocene); 5-sands, gravels and alluvial loams (Pleistocene); 6marginal clays, loams and sands (Pleistocene); 7 - outwash sands and gravels (Pleistocene); 8 - end moraine gravels, sands, boulders and clays, glacial tills, glacial till waste and glacial sands and gravels (Pleistocene); 9 - organodetritic limestones, sulphur-bearing limestones, gravels, clays, loams, sands, locally gypsum and lignite (Neogene); 10

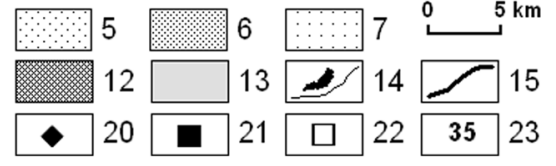

limestones, marls, dolomites, mudstones, sandstones, claystones, with flints and siderite insertions, gravels, conglomerates, sands, clays and fire clays (Jurassic); 11 - claystones, mudstones, sandstones, limestones, dolomites, marls, oolitic limestones, gypsum, anhydrite, epigenetic ore-bearing dolomites, iron ores (Triassic); 12conglomerates, arkosic sandstones, mudstones, claystones (Perm); 13 sandstones, conglomerates, claystones, mudstones, coal (Carboniferous); 14 -waterways and water bodies; 15-watershed; 16 - actively mined coal deposits; 17 — zinc and lead ore deposits; 18 - power plants; 19 cement factories; 20-steelworks, smelters; 21 -metallurgical processing plants or smelters (zinc and lead); 22 -former smelters (zinc and lead); 23 - water body labels (see Fig. 2) 


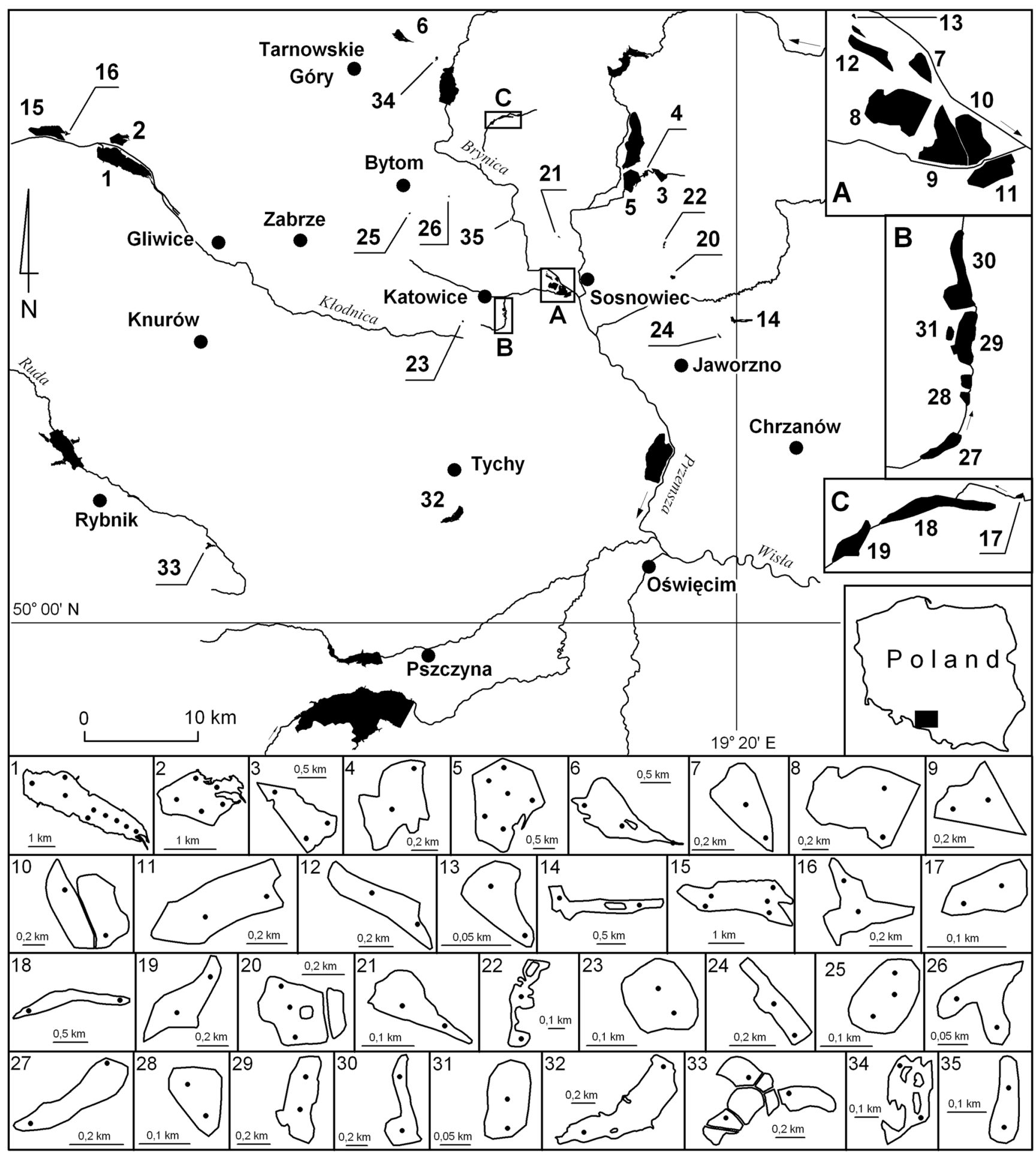

Fig. 2 Water bodies examined in the Silesian Upland: 1 Dzierżno Duże, 2 Dzierżno Małe, 3 Pogoria I, 4 Pogoria II, 5 Pogoria III, 6 Chechło, 7 Stawiki, 8 - Morawa, 9 Hubertus I, 10 Gliniak, 11 Hubertus II, 12 Borki, 13 Borki Małe, 14 Sosina, 15 Pławniowice, 16 Mały Zalew, 17 Rogoźnik
E, 18 Rogoźnik I (central), 19 Rogoźnik W, 20 Balaton, 21 Czeladź Norwida, 22 Kazimierz, 23 Gliniok, 24 Koparki, 25 Amendy, 26 Brzeziny, 27 Milicyjny, 28 Mały, 29 Kajakowy, 30 Łaka, 31 Ozdobny, 32 Paprocany, 33 Kradziejówka, 34 Ostrożnica, 35 Przetok $\left.16,500 \mu \mathrm{S} \mathrm{cm}^{-1}\right)$, nitrate concentrations $\left(1.0-42.2 \mathrm{mg} \mathrm{NO}_{3}\right.$ $\mathrm{dm}^{-3}$ ) and phosphate concentrations $\left(0.0-5.1 \mathrm{PO}_{4}{ }^{3-} \mathrm{dm}^{-3}\right)$.
Bottom sediment samples were collected using the Beeker loose sediment sampler (04.20.S.A version, manufactured by 
Table 1 Morphometric and hydrometric parameters of the water bodies studied (after Rzętała 2014; revised and supplemented)

\begin{tabular}{|c|c|c|c|c|c|}
\hline Characteristics & $\begin{array}{l}\text { Total capacity } \\
\left(\text { dam }^{3}\right)\end{array}$ & $\begin{array}{l}\text { Maximum area } \\
\text { (ha) }\end{array}$ & $\begin{array}{l}\text { Electrolytic conductivity } \\
\left(\mu \mathrm{S} \mathrm{cm}^{-1}\right)\end{array}$ & $\begin{array}{l}\text { Nitrates }\left(\mathrm{NO}_{3}^{-}\right) \\
\left(\mathrm{mg} \mathrm{dm}^{-3}\right)\end{array}$ & $\begin{array}{l}\text { Phosphates }\left(\mathrm{PO}_{4}{ }^{3-}\right) \\
\left(\mathrm{mg} \mathrm{dm}^{-3}\right)\end{array}$ \\
\hline Minimum & 6.0 & 0.9 & 183.0 & 1.0 & 0.0 \\
\hline Maximum & $94,000.0$ & 561.0 & $16,500.0$ & 42.2 & 5.1 \\
\hline Average & 4596.8 & 49.9 & 1452.4 & 18.0 & 0.8 \\
\hline Median & 202.0 & 9.0 & 651.0 & 19.3 & 0.1 \\
\hline First quartile & 57.0 & 2.9 & 485.5 & 7.0 & 0.1 \\
\hline Third quartile & 796.5 & 36.7 & 733.0 & 26.9 & 1.1 \\
\hline Standard deviation & 16509.3 & 106.8 & 3009.9 & 12.3 & 1.4 \\
\hline
\end{tabular}

Eijkelkamp). The use of a sampler with a transparent sediment tube with guides, a built-in hammer, pneumatic lower closing element and several other improvements made it possible to collect sediments with a virtually undisturbed structure. Samples were additionally collected using a van Veen sampler with a capacity of 1.25 or $2.50 \mathrm{dm}^{3}$. As there were very few sediments on the rocky bottom of the Koparki water body, samples were collected directly into a polystyrene container by a team of divers. Depending on the surface area and morphometric characteristics, from 2 to 9 samples representative in terms of sediment thickness were collected in each water body (92 samples in total). Samples were collected in polystyrene containers or polyethylene bags and transported to the laboratory. During the deposition of the material collected for testing in containers (bags), mixed samples were prepared that were representative of the vertical sediment profile. The vertical sediment profile is assumed to be representative of the entire layer of sediments found on the bottom, which exhibited limited thickness in most cases. These deposits tend to be unconsolidated, often have thixotropic characteristics and may also be subject to periodic inactivation in the water mass. Mixed samples were considered to best reflect the general geoecological state of sediments, which is representative of anthropogenic lakes that are often only a few decades old.

The basic preparation of the sediment samples for laboratory tests of their geochemical composition was carried out at the Faculty of Earth Sciences of the University of Silesia. After the material had been dried at a temperature of $105^{\circ} \mathrm{C}$, it was ground in a mortar. The $<0.063-\mathrm{mm}$ fraction was then separated using chemically inert sieves. Cadmium concentrations were determined at Activation Laboratories Ltd. (Ancaster, Canada) from 0.25-g aliquots using the total digestion ICP method. The sample aliquots were digested with a mixture of $\mathrm{HClO}_{4}, \mathrm{HNO}_{3}, \mathrm{HCl}$ and $\mathrm{HF}$ at $200{ }^{\circ} \mathrm{C}$ to fuming and were then diluted with aqua regia (www.actlabs.com 2016 ). The sample solutions were also spiked with internal standards and further diluted and introduced into a Perkin Elmer SCIEX ELAN 6000 ICP-MS. The tests were performed at a $\mathrm{Cd}$ detection level of $0.5 \mathrm{mg} \mathrm{kg}^{-1}$ and an upper limit of quantification of $5000 \mathrm{mg} \mathrm{kg}^{-1}$. The precision and accuracy of the analyses conducted using the PERKIN ELMER Model 6000 spectrometer are as follows: (a) at the lower limit of detection $\pm 100 \%$; (b) at 10 times the lower limit of detection $\pm 15-20 \%$ and (c) at 100 times the lower limit of detection $>10 \%$.

The geoaccumulation index $\left(\mathrm{I}_{\text {geo }}\right)$ algorithm for geochemical sediment studies proposed by Müller (1979) was used as follows:

$I_{g e o}=\log _{2} \frac{C_{n}}{1.5 B_{n}}$

where

$C_{n}$ is concentration of the element in question in bottom sediments, $B_{n}$ is geochemical background for the element in question and 1.5 is the coefficient expressing natural variation in the content of the element in question in the environment.

The $I_{\text {geo }}$ has several classes of sediment quality (Müller 1979): class $0\left(\mathrm{I}_{\mathrm{geo}} \leq 0.0\right)$ —practically uncontaminated; class I-uncontaminated to moderately contaminated $\left(0.0<\mathrm{I}_{\mathrm{geo}}<1.0\right)$; class II-moderately contaminated $\left(1.0<\mathrm{I}_{\mathrm{geo}}<2.0\right)$; class III-moderately to heavily contaminated $\left(2.0<\mathrm{I}_{\text {geo }}<3.0\right)$; class IV-heavily contaminated $\left(3.0<\mathrm{I}_{\text {geo }}<4.0\right)$; class $\mathrm{V}$ - heavily to extremely contaminated $\left(4.0<\mathrm{I}_{\mathrm{geo}}<5.0\right)$ and class $\mathrm{VI}$ - extremely contaminated $\left(5.0<\mathrm{I}_{\text {geo }}\right)$.

The $\mathrm{I}_{\text {geo }}$ index is widely used in sediment contamination studies (e.g. Müller 1979, 1986; Förstner and Müller 1981). Its advantage is that it offers the possibility of assessing sediment contamination in various sedimentary environments. In the case of aquatic ecosystems, this index is commonly used for marine (Özkan 2012; Attia and Ghrefat 2013; Ong et al. 2013), fluvial (Bojakowska and Sokołowska 1998; Ghrefat and Yusuf 2006; Nikolaidis et al. 2010; Kabir et al. 2011; Rabee et al. 2011; Rubin et al. 2011; Varol and Sen 2012; Yahaya et al. 2012; Kalender and Uçar 2013), lake (Zeng and Wu 2009; Choiński et al. 2010; Bing et al. 2011; Hu et al. 2011; Cáceres Choque et al. 2013; Alikaj et al. 2014; 
El-Sayed et al. 2015; Gao et al. 2015; Guo et al. 2015) and reservoir sediments (Loska and Wiechuła 2003; Saleem et al. 2012; Young et al. 2012; Bak et al. 2013; Goher et al. 2014; Tang et al. 2014; Wang et al. 2014; Palma et al. 2015) as well as in marshes and peats (Bai et al. 2012) in various climatic zones.

Modern applications of the $\mathrm{I}_{\text {geo }}$ are also varied; even for the algorithm for calculating, it takes different forms. The essence of the problems arising in relation to interpretation is the value of the geochemical background that is used in the calculation of the index for the element in question. Some researchers base their interpretations of element concentrations in sediments on a calculation formula that uses the presence of the element in question in a certain type of rock in the Earth's crust as the geochemical background (Loska and Wiechula 2003; Ghrefat and Yusuf 2006; Hu et al. 2011; Saleem et al. 2012; Young et al. 2012; Goher et al. 2014; El-Sayed et al. 2015). Most commonly, the geochemical background for individual elements is used (Turekian and Wedepohl 1961; Bowen 1966; Li 2000; Li and Schoonmaker 2005). Equally popular is a solution in which the geochemical background of a region (Lis and Pasieczna 1995a, 1995b; Tylmann et al. 2011; Guo et al. 2015; Rzętała 2015a; 2015b; 2015c) or study area (Tylmann et al. 2011; Tang et al. 2014) is taken into account, as well as the preindustrial content of the element in question in the environment (Håkanson 1980).

\section{Results}

Cadmium was present in the bottom sediments of the water bodies in amounts ranging from 0.7 to $580.0 \mathrm{mg} \mathrm{kg}^{-1}$ (Fig. 3). The minimum concentration from this range concerned a sediment sample from the Pogoria III water body, and the maximum one was for a sample from the Brzeziny water body. The lowest $\mathrm{Cd}$ concentrations were found in the bottom sediments of three flooded mineral workings: Gliniok $\left(1.2 \mathrm{mg} \mathrm{kg}^{-1}\right)$, Kradziejówka (1.5-2.5 mg kg$\left.{ }^{-1}\right)$ and Pławniowice (1.8$1.9 \mathrm{mg} \mathrm{kg}^{-1}$ ). The highest concentrations were found in the bottom sediments of the Brzeziny (540-580.0 mg kg-1), Hubertus I (274.0-444.0 $\mathrm{mg} \mathrm{kg}^{-1}$ ), Gliniak (172.0$286.0 \mathrm{mg} \mathrm{kg}^{-1}$ ) and Morawa (119.0 $\mathrm{mg} \mathrm{kg}^{-1}$ ) water bodies.

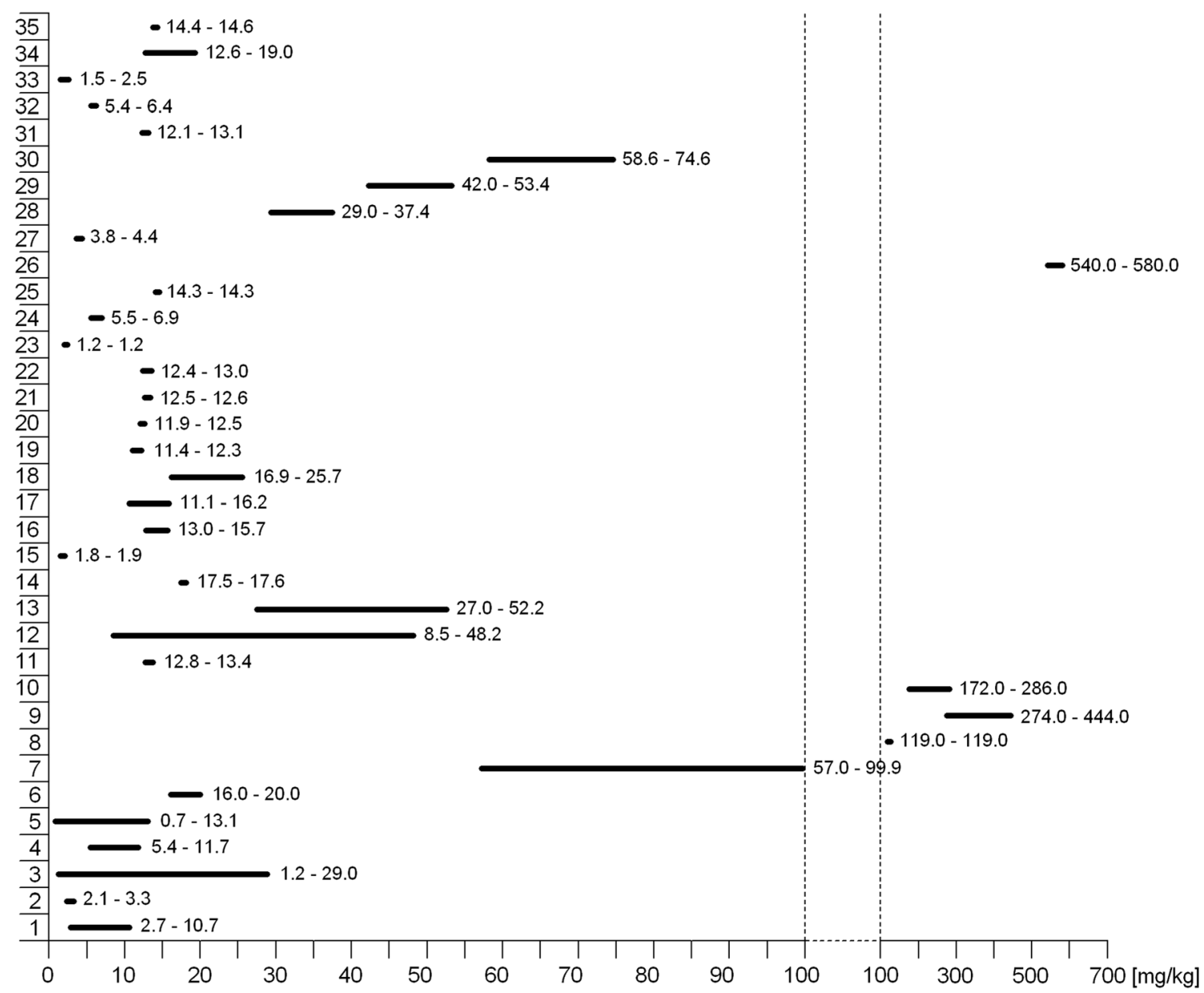

Fig. 3 Cadmium content in the bottom sediments of the water bodies examined (water body numbering as in Fig. 2) 
The arithmetic mean of $\mathrm{Cd}$ concentrations for individual water bodies ranged from 1.2 to $560.0 \mathrm{mg} \mathrm{kg}{ }^{-1}$ (Fig. 4). The arithmetic mean of $\mathrm{Cd}$ concentrations in the bottom sediments, calculated for 35 water bodies on the basis of their individual mean values, was $52.1 \mathrm{mg} \mathrm{kg}^{-1}$ with a median equal to $14.3 \mathrm{mg} \mathrm{kg}^{-1}$ (first quartile $-8.1 \mathrm{mg} \mathrm{kg}^{-1}$, third quartile- $30.8 \mathrm{mg} \mathrm{kg}^{-1}$ ) and a standard deviation of $113.0 \mathrm{mg} \mathrm{kg}{ }^{-1}$. The statistical characteristics calculated for minimum concentrations of $\mathrm{Cd}$ in the sediments of the water bodies are as follows: $0.7-540.0 \mathrm{mg} \mathrm{kg}^{-1}$ (range of variation), $12.5 \mathrm{mg} \mathrm{kg}^{-1}$ (median), $44.2 \mathrm{mg} \mathrm{kg}^{-1}$ (arithmetic mean) and $102.2 \mathrm{mg} \mathrm{kg}^{-1}$ (standard deviation). The corresponding parameters for maximum concentrations are as follows: $1.2-580.0 \mathrm{mg} \mathrm{kg}^{-1}$ (range of variation), $14.4 \mathrm{mg} \mathrm{kg}^{-1}$ (median), $60.2 \mathrm{mg} \mathrm{kg}^{-1}$ (arithmetic mean) and $125.2 \mathrm{mg} \mathrm{kg}^{-1}$ (standard deviation).

\section{Discussion}

\subsection{Cadmium in Silesian reservoirs}

Cadmium is present in the upper layer of the Earth's crust at a concentration of $0.1 \mathrm{mg} \mathrm{kg}^{-1}$ on average (Taylor and McLennan 1995; Li 2000; Li and Schoonmaker 2005). Turekian and Wedepohl (1961) state that this element is present at slightly higher levels $\left(0.3 \mathrm{mg} \mathrm{kg}^{-1}\right)$ in some types of sedimentary rock. On the other hand, Bowen (1966) states that the $\mathrm{Cd}$ content in sedimentary rocks ranges from 0.035 to $0.3 \mathrm{mg} \mathrm{kg}^{-1}$. Kabata-Pendias and Pendias (1979) and Taylor (1964) state that the average Cd content in the Earth's crust ranges from 0.15 to $0.20 \mathrm{mg} \mathrm{kg}^{-1}$. Given these natural limits to $\mathrm{Cd}$ content, it can be concluded that the concentration of this element in all the samples of bottom sediment in water bodies in the Silesian Upland was higher than the natural
Fig. 4 Cadmium content (average value) in the bottom sediments of the water bodies examined (water body numbering as in Fig. 2)

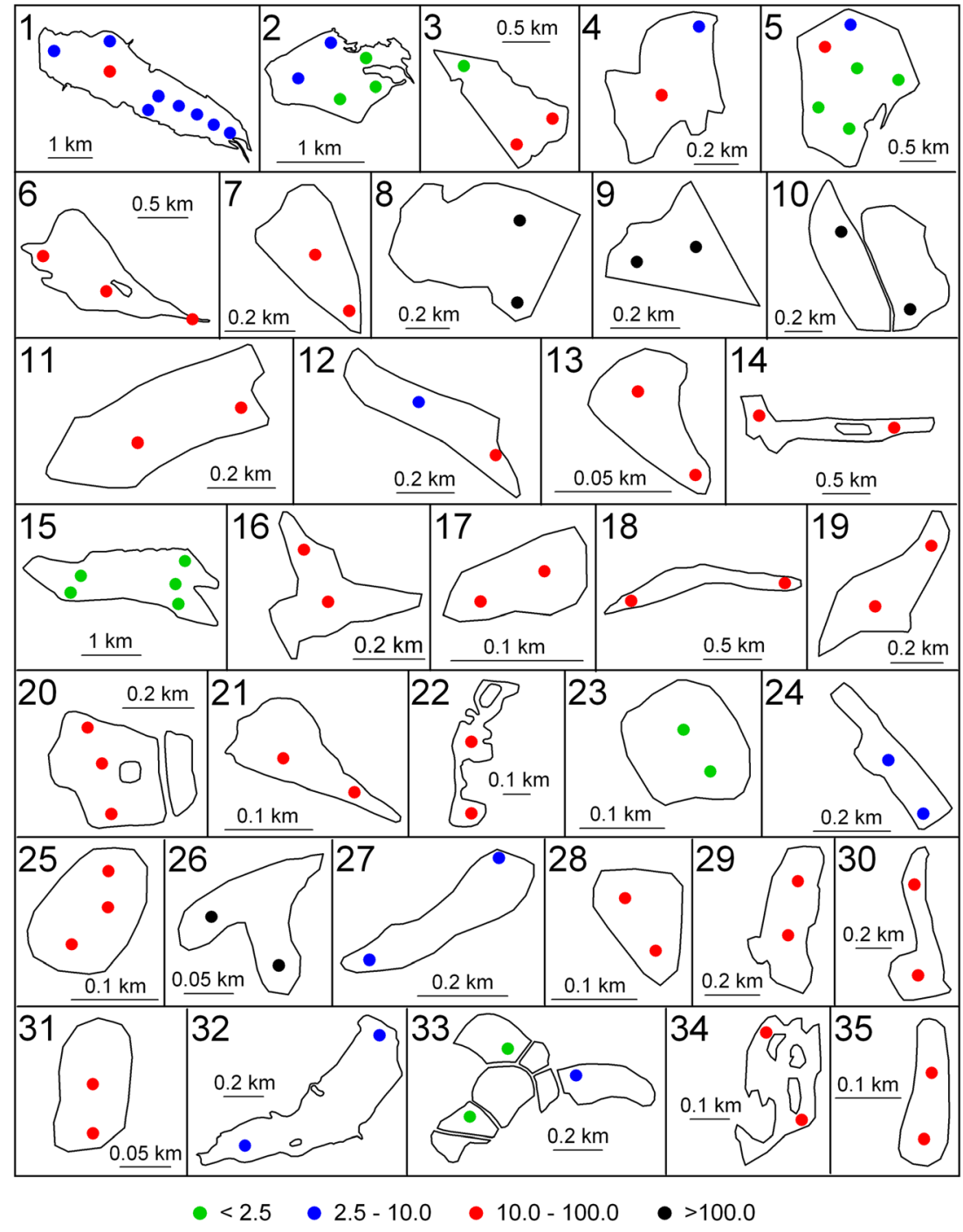


range of concentrations for this element, often by several orders of magnitude.

In all the water bodies examined, the concentration of $\mathrm{Cd}$ in bottom sediments is greater than the preindustrial content of this element $\left(1.0 \mathrm{mg} \mathrm{kg}^{-1}\right)$ in sediments of Eurasian and American lakes as suggested by Håkanson (1980). The Cd content found in the bottom sediments is still higher than the geochemical background for Poland determined at below $0.5 \mathrm{mg} \mathrm{kg}^{-1}$ by Lis and Pasieczna (1995a). For the sediments examined, in only a few cases is the threshold geochemical background value for $\mathrm{Cd}$ in aqueous sediments in Poland $\left(1.8 \mathrm{mg} \mathrm{kg}^{-1}\right)$ not reached (Lis and Pasieczna 1995b). For aqueous sediments in the Upper Silesia region, the geochemical background for $\mathrm{Cd}$ is only slightly higher at $2.5 \mathrm{mg} \mathrm{kg}^{-1}$ (Lis and Pasieczna 1995b). This means that the concentration of $\mathrm{Cd}$ in the sediments of just three water bodies examined was lower than the regional geochemical background, and in the other ones, this background level was exceeded significantly.

Causes for the variation in $\mathrm{Cd}$ concentrations in bottom sediments between individual water bodies include differences in natural factors (these are usually related to geological structure) but primarily relate to human pressure, particularly, land use in the catchment and air pollution. Similar considerations apply to differences in the concentration of other metals, non-metals and metalloids in the region (Rzętała 2015a; 2015b) and in other parts of the world (Astrom and Nylund 2000; O'Neill et al. 2015).

The role of anthropogenic factors that condition the accumulation of $\mathrm{Cd}$ in sediments is well documented by the example of the water bodies most contaminated with this element (i.e. Brzeziny, Hubertus I, Gliniak, Morawa, Stawiki). The Brzeziny water body lies in the immediate vicinity of spoil tips derived from the smelting of $\mathrm{Pb}$ and $\mathrm{Zn}$ ores. It is fed by leachate water from a spoil tip and the material deposited there also finds its way to the basin of the water body. The Hubertus I, Gliniak, Morawa and Stawiki water bodies are located in an area subject to the long-term impact of a non-ferrous metal smelter. Cd contamination is also the result of the storage of the waste produced by non-ferrous metal smelting within the basins of water bodies, its use in rehabilitation work and in the construction of transport infrastructure. On the other hand, Chechło Lake is an example of a local sedimentary basin where $\mathrm{Cd}$ is supplied by atmospheric deposition from a nearby non-ferrous metal smelter. The accumulation of $\mathrm{Cd}$ in the sediments of the aforementioned water bodies is permanent to the extent that the mobility of this element is limited by the alkalinity of the environment in which it is deposited. However, the catchments of these water bodies are particularly prone to acidification because they include sandy formations and are covered with coniferous forests as well as being affected by human-made pollution.

$\mathrm{Cd}$ in amounts of several tens of $\mathrm{mg} \mathrm{kg}^{-1}$ has been found in the bottom sediments of several ponds (i.e. Milicyjny, Mały,
Kajakowy, Łaka) that form a cascade along a single stream. In the catchment of that stream, woodland dominates alongside urbanised and industrialised areas (each of the two categories account for $45 \%$ of the total area) (Rzętała 2015a). The first water body in the cascade formed along the stream exhibits the lowest pollution level, while each subsequent water body has higher concentrations of $\mathrm{Cd}$ in bottom sediments. The fact that $\mathrm{Cd}$ concentrations in bottom sediments increase downstream is explained by the long-term supply of the water drained from communication routes to these water bodies and the migration of pollutants from the areas where waste from non-ferrous smelters is stored (Molenda 2001; Jankowski et al. 2002). The concentration of Cd in the bottom sediments of another water body (no. 31) located in the vicinity of this stream is much lower, which may demonstrate the scale of pollution from atmospheric deposition, which is characteristic of urban-industrial areas. Where water bodies are cascaded, the concentration of $\mathrm{Cd}$ in the bottom sediments of the subsequent water body is usually lower than in the preceding one if there is no additional supply of pollutants. Between the Pogoria I (no. 3) and Pogoria II (no. 4) lakes along the Pogoria stream and between the Rogoźnik E (no. 17) and Rogoźnik I (no. 18) lakes along the Jaworznik stream, the concentration of $\mathrm{Cd}$ in bottom sediments increases due to the impact of coal mining waste tips. The following water bodies along these streams (i.e. Pogoria III (no. 5) and Rogoźnik W (no. 19)), exhibit much lower Cd contamination levels in bottom sediments. This demonstrates the high potential for pollutant accumulation in sequential water bodies within cascades. The accumulation of $\mathrm{Cd}$ in the bottom sediments of flow-through water bodies can be regarded as a sign that river water and fluvial sediments undergo selfpurification.

The concentration of $\mathrm{Cd}$ in the bottom sediments of the remaining water bodies is too high for these to be deemed uncontaminated. Artificial lakes and ponds in catchments with an urban-industrial character (e.g. Dzierżno Duże, Gliniok, Amendy, Przetok) exhibit slightly higher Cd content in bottom sediments compared to those in catchment areas that are used for agricultural purposes (e.g. Pławniowice, Dzierżno Małe) or that are largely forested (e.g. Balaton, Sosina).

In some cases, $\mathrm{Cd}$ concentrations (ranging from 0.7 to $580.0 \mathrm{~m} \mathrm{~kg}^{-1}$ ) in the bottom sediments of water bodies in the Silesian Upland are so high that no comparable levels can be found anywhere else in the world. Concentrations of $\mathrm{Cd}$ in the bottom sediments of other water bodies in southern Poland are not that extreme. Studies of the bottom sediments in 20 water bodies in the same region (that also covered several of those included in this study) which were conducted a few years earlier revealed the presence of $\mathrm{Cd}$ in amounts ranging from 0.9 to $50.3 \mathrm{mg} \mathrm{kg}^{-1}$ (Rzętała et al. 2013). In the bottom sediments of the Rybnik Reservoir, $\mathrm{Cd}$ was found in amounts ranging from 2.40 to $85.06 \mathrm{mg} \mathrm{kg}^{-1}$ 
(average $=25.81 \mathrm{mg} \mathrm{kg}^{-1}$ ) (Loska and Wiechuła 2003). In studies of heavy metal content in the bottom sediments of 19 water bodies near Kraków, $\mathrm{Cd}$ was found at levels ranging from 0.2 to $36.5 \mathrm{mg} \mathrm{kg}^{-1}$ (Ciszewski et al. 1998). Sediments in lakes in northeastern Poland contain $\mathrm{Cd}$ at an average of $<0.5 \mathrm{mg} \mathrm{kg}^{-1}$ (Tylmann et al. 2011).

The same is true of other lakes in Europe and throughout the world. During the study of bottom sediments in 49 lakes in Latvia, Cd ranged from 0.15 to $8.41 \mathrm{mg} \mathrm{kg}^{-1}$ (Klavinš et al. 1995). In Lake Balaton in Hungary, sediments with Cd concentrations ranging from 0.1 to $0.7 \mathrm{mg} \mathrm{kg}^{-1}$ were found (Nguyen et al. 2005). In Norwegian lakes, Cd was found in bottom sediments at levels from 0.06 to $3.12 \mathrm{mg} \mathrm{kg}^{-1}$ (Rognerud et al. 2000). Cd levels in the sediments of Kalimanci Lake in Macedonia range from 16.5 to $136.0 \mathrm{mg} \mathrm{kg}^{-1}$ (Vrhovnik et al. 2013). In the Kapulukaya Dam Lake in Turkey, Cd is present in sediments in the range 0.5 to $1.8 \mathrm{mg} \mathrm{kg}^{-1}$ (Kankilic et al. 2013). In sediments of the Lake Nasser Reservoir, $\mathrm{Cd}$ was found in amounts ranging from $0.00-0.45 \mathrm{mg} \mathrm{kg}^{-1}$ (Goher et al. 2014) to $4.5-8.0 \mathrm{mg} \mathrm{kg}^{-1}$ (Moalla et al. 1998). Sediments in the Wadi Al-Arab Dam Reservoir in Jordan contain from 6 to $13 \mathrm{mg} \mathrm{kg}^{-1}$ of $\mathrm{Cd}$ (Ghrefat and Yusuf 2006). The bottom sediments of Vembanad Lake in India contain $\mathrm{Cd}$ at levels ranging from 0.07 to $10.5 \mathrm{mg} \mathrm{kg}^{-1}$ (Selvam et al. 2013). The sediments of Lake Songkhla in Thailand contain $<2.5 \mathrm{mg} \mathrm{kg}^{-1}$ of Cd (Pradit et al. 2010, 2013). Bottom sediments in Lake Hope in Ohio, USA, contain $0.26-0.52 \mathrm{mg} \mathrm{kg}^{-1}$ of Cd on average (Lopez et al. 2010).

Many lakes in China in which the $\mathrm{Cd}$ content in the bottom sediments was measured exhibit low concentrations, often $<1$ of $\mathrm{mg} \mathrm{kg}^{-1}$ : Nansi Lake- from 0.058 to $0.458 \mathrm{mg} \mathrm{kg}^{-1}$ (Wang et al. 2014); Mangla Lake-from 0.05 to $4.08 \mathrm{mg} \mathrm{kg}^{-1}$ (Saleem et al. 2012); Taihu Lake-from 0.027 to $4.086 \mathrm{mg} \mathrm{kg}^{-1}$ (Tao et al. 2012) and $0.11 \mathrm{mg} \mathrm{kg}^{-1}$ (Zeng et al. 2013); Hulun Lake- $0.02 \mathrm{mg} \mathrm{kg}^{-1}$ (Zeng et al. 2013); Three Gorges Reservoir-from 0.60 to $1.17 \mathrm{mg} \mathrm{kg}^{-1}$ (Tang et al. 2014); Xijiu Lake-12.1 $\mathrm{mg} \mathrm{kg}^{-1}$ on average (Bing et al. 2011); the Yangtze River Region (14 lakes) - from 0.22 to $0.85 \mathrm{mg} \mathrm{kg}^{-1}$ (Guo et al. 2015); the Yunnan-Guizhou Plateau (seven lakes) - from 0.61 to $1.08 \mathrm{mg} \mathrm{kg}^{-1}$ (Guo et al. 2015); the Qinghai-Tibet Plateau (four lakes) - from 0.11 to $0.61 \mathrm{mg} \mathrm{kg}^{-1}$ (Guo et al. 2015); the Northeast China Region (four lakes) -0.14 to $1.95 \mathrm{mg} \mathrm{kg}^{-1}$ (Guo et al. 2015) and the Mongolia-Xinjiang Plateau (five lakes)-from 0.08 to $0.18 \mathrm{mg} \mathrm{kg}^{-1}$ (Guo et al. 2015). In the sediments of lakes located in the urban areas of Beijing, $\mathrm{Cd}$ is present in amounts ranging from 0.14 to $1.22 \mathrm{mg} \mathrm{kg}^{-1}$ (Xuanwu Lake) and from 0.62 to $1.19 \mathrm{mg} \mathrm{kg}^{-1}$ (Mochou Lake) (Hu et al. 2011).

The presence of $\mathrm{Cd}$ in the bottom sediments of water bodies at levels that exceed those considered natural is a local, regional and global environmental problem that should be recognised in terms of its natural and socioeconomic impacts.
First of all, the increased mobility of the Cd deposited in sediments poses a geoecological hazard as the environment becomes increasingly acidified, which has been identified for many years (Newell and Skjelkvale 1997; Chen et al. 2004; Sienkiewicz et al. 2006; Stuchlik et al. 2006). The high degree of bioaccumulation and the possibility that $\mathrm{Cd}$ could become mobile in an acidic environment as a result of human activities mean that there is a risk of environmental contamination, and the safe operation of reservoirs could be affected, including difficulties with sourcing water for municipal purposes and the mortality of fish and other aquatic organisms (Jankowski et al. 2002). Another geoecological issue is the transport of pollutants along waterways to areas that were not hitherto polluted; for example, Dzierżno Duże Lake accumulates pollution from distant urban and industrial areas in its sediments.

\subsection{Interpretation of $I_{g e o}$ values}

The $I_{\text {geo }}$ has been used for several decades and many interpretations of the results have been put forward which have been related to the use of different geochemical background figures. Thus, slightly different results and syntheses have emerged, and the conclusions drawn from them also differ. These differences are reflected not so much in the $I_{\text {geo }}$ calculation formula but rather in the possibility of using different geochemical background values (Müller 1979). This is clearly demonstrated by $I_{\text {geo }}$ calculations and by the different interpretations of the $\mathrm{Cd}$ concentrations in the bottom sediments in water bodies in the Silesian Upland (Table 2).

Depending on the geochemical background adopted $\left(0.1,0.3,1.0\right.$ and $\left.2.5 \mathrm{mg} \mathrm{kg}^{-1}\right), \mathrm{I}_{\text {geo }}$ values for the minimum $\mathrm{Cd}$ concentrations in the bottom sediments of the water bodies studied are 2.2-11.8, 0.6-10.2, -1.1 to 8.5 and -2.4 to 7.2 , respectively. These values translate into a geochemical assessment of the quality of sediments depending on the geochemical background adopted, i.e. we may find a prevalence of water bodies with sediment classes 0 , I and II or-conversely-state that those with extremely contaminated sediments dominate. The situation is similar with respect to the interpretation of $I_{\text {geo }}$ values for the maximum concentrations of Cd. Depending on the geochemical background adopted $\left(0.1,0.3,1.0\right.$ and $\left.2.5 \mathrm{mg} \mathrm{kg}^{-1}\right)$, the $I_{\text {geo }}$ values are $3.0-11.9,1.4-10.3,-0.3$ to 8.6 and -1.6 to 7.3 , respectively. Similarly as in the previous case, the quality of bottom sediments may be judged as ranging from uncontaminated to moderately contaminated or as predominantly extremely contaminated.

Although the classification of sediments according to the geochemical background for Cd in the Earth's crust cannot be described as incorrect, a reference to the regional geochemical 
Table 2 Geoaccumulation index values ( $\left.\mathrm{I}_{\text {geo }}\right)$ for the minimum and maximum cadmium concentrations $\left(\mathrm{Cd}_{\min }, \mathrm{Cd}_{\max }\right)$ in bottom sediments and different geochemical background values for cadmium $\left(\mathrm{B}_{\mathrm{Cd}}\right)$

\begin{tabular}{|c|c|c|c|c|c|c|c|c|c|}
\hline \multirow{3}{*}{\multicolumn{2}{|c|}{$\begin{array}{c}\text { Water body name } \\
\text { (numbering as in Fig. 1) }\end{array}$}} & \multicolumn{8}{|c|}{ Geochemical background $\left(\mathrm{B}_{\mathrm{Cd}}\right)$} \\
\hline & & $0.1^{1)}$ & $0.3^{2)}$ & $1.0^{3)}$ & $2.5^{4)}$ & $0.1^{1)}$ & $0.3^{2)}$ & $1.0^{3)}$ & $2.5^{4)}$ \\
\hline & & \multicolumn{4}{|c|}{$I_{\text {geo }}\left(C_{n}=C d_{\min }\right)$} & \multicolumn{4}{|c|}{$\mathrm{I}_{\text {geo }}\left(\mathrm{C}_{\mathrm{n}}=\mathrm{Cd}_{\max }\right)$} \\
\hline 1 & Dzierżno Duże & 4.17 & 2.58 & 0.85 & -0.47 & 6.16 & 4.57 & 2.83 & 1.51 \\
\hline 2 & Dzierżno Małe & 3.81 & 2.22 & 0.49 & -0.84 & 4.46 & 2.87 & 1.14 & -0.18 \\
\hline 3 & Pogoria I & 3.00 & 1.42 & -0.32 & -1.64 & 7.59 & 6.01 & 4.27 & 2.95 \\
\hline 4 & Pogoria II & 5.17 & 3.58 & 1.85 & 0.53 & 6.29 & 4.70 & 2.96 & 1.64 \\
\hline 5 & Pogoria III & 2.22 & 0.64 & -1.10 & -2.42 & 6.45 & 4.86 & 3.13 & 1.80 \\
\hline 6 & Chechło & 6.74 & 5.15 & 3.42 & 2.09 & 7.06 & 5.47 & 3.74 & 2.42 \\
\hline 7 & Stawiki & 8.57 & 6.98 & 5.25 & 3.93 & 9.38 & 7.79 & 6.06 & 4.74 \\
\hline 8 & Morawa & 9.63 & 8.05 & 6.31 & 4.99 & 9.63 & 8.05 & 6.31 & 4.99 \\
\hline 9 & Hubertus I & 10.83 & 9.25 & 7.51 & 6.19 & 11.53 & 9.95 & 8.21 & 6.89 \\
\hline 10 & Gliniak & 10.16 & 8.58 & 6.84 & 5.52 & 10.90 & 9.31 & 7.57 & 6.25 \\
\hline 11 & Hubertus II & 6.42 & 4.83 & 3.09 & 1.77 & 6.48 & 4.90 & 3.16 & 1.84 \\
\hline 12 & Borki & 5.82 & 4.24 & 2.50 & 1.18 & 8.33 & 6.74 & 5.01 & 3.68 \\
\hline 13 & Borki Małe II & 7.51 & 5.93 & 4.19 & 2.87 & 8.44 & 6.86 & 5.12 & 3.80 \\
\hline 14 & Sosina & 6.87 & 5.28 & 3.54 & 2.22 & 6.87 & 5.29 & 3.55 & 2.23 \\
\hline 15 & Pławniowice & 3.58 & 2.00 & 0.26 & -1.06 & 3.66 & 2.08 & 0.34 & -0.98 \\
\hline 16 & Mały Zalew & 6.44 & 4.85 & 3.12 & 1.79 & 6.71 & 5.12 & 3.39 & 2.07 \\
\hline 17 & Rogoźnik E & 6.21 & 4.62 & 2.89 & 1.57 & 6.75 & 5.17 & 3.43 & 2.11 \\
\hline 18 & Rogoźnik I (central) & 6.82 & 5.23 & 3.49 & 2.17 & 7.42 & 5.84 & 4.10 & 2.78 \\
\hline 19 & Rogoźnik W & 6.25 & 4.66 & 2.93 & 1.60 & 6.36 & 4.77 & 3.04 & 1.71 \\
\hline 20 & Balaton & 6.31 & 4.72 & 2.99 & 1.67 & 6.38 & 4.80 & 3.06 & 1.74 \\
\hline 21 & Czeladź Norwida & 6.38 & 4.80 & 3.06 & 1.74 & 6.39 & 4.81 & 3.07 & 1.75 \\
\hline 22 & Kazimierz & 6.37 & 4.78 & 3.05 & 1.73 & 6.44 & 4.85 & 3.12 & 1.79 \\
\hline 23 & Gliniok & 3.00 & 1.42 & -0.32 & -1.64 & 3.00 & 1.42 & -0.32 & -1.64 \\
\hline 24 & Koparki & 5.20 & 3.61 & 1.87 & 0.55 & 5.52 & 3.94 & 2.20 & 0.88 \\
\hline 25 & Amendy & 6.57 & 4.99 & 3.25 & 1.93 & 6.57 & 4.99 & 3.25 & 1.93 \\
\hline 26 & Brzeziny & 11.81 & 10.23 & 8.49 & 7.17 & 11.92 & 10.33 & 8.59 & 7.27 \\
\hline 27 & Milicyjny & 4.66 & 3.08 & 1.34 & 0.02 & 4.87 & 3.29 & 1.55 & 0.23 \\
\hline 28 & Mały & 7.59 & 6.01 & 4.27 & 2.95 & 7.96 & 6.38 & 4.64 & 3.32 \\
\hline 29 & Kajakowy & 8.13 & 6.54 & 4.81 & 3.49 & 8.48 & 6.89 & 5.15 & 3.83 \\
\hline 30 & Łąka & 8.61 & 7.02 & 5.29 & 3.97 & 8.96 & 7.37 & 5.64 & 4.31 \\
\hline 31 & Ozdobny & 6.33 & 4.75 & 3.01 & 1.69 & 6.45 & 4.86 & 3.13 & 1.80 \\
\hline 32 & Paprocany & 5.17 & 3.58 & 1.85 & 0.53 & 5.42 & 3.83 & 2.09 & 0.77 \\
\hline 33 & Kradziejówka & 3.32 & 1.74 & 0.00 & -1.32 & 4.06 & 2.47 & 0.74 & -0.58 \\
\hline 34 & Ostrożnica & 6.39 & 4.81 & 3.07 & 1.75 & 6.98 & 5.40 & 3.66 & 2.34 \\
\hline 35 & Przetok & 6.60 & 5.02 & 3.28 & 1.96 & 6.58 & 5.00 & 3.26 & 1.94 \\
\hline
\end{tabular}

Explanations: ${ }^{1)}$ according to: Taylor and McLennan (1995); Li (2000); Li and Schoonmaker (2005); 2) according to: Turekian and Wedepohl (1961); ${ }^{3)}$ according to: Håkanson (1980); ${ }^{4)}$ according to: Lis and Pasieczna (1995b).

\begin{tabular}{|l}
\hline class 0 - practically uncontaminated $\left(\mathrm{I}_{\text {geo }} \leq 0.0\right)$, \\
class $\mathrm{I}$ - uncontaminated to moderately contaminated $\left(0.0<\mathrm{I}_{\text {geo }}<1.0\right)$, \\
class $\mathrm{II}$ - moderately contaminated $\left(1.0<\mathrm{I}_{\text {geo }}<2.0\right)$, \\
class III - moderately to heavily contaminated $\left(2.0<\mathrm{I}_{\text {geo }}<3.0\right)$, \\
class IV - heavily contaminated $\left(3.0<\mathrm{I}_{\text {geo }}<4.0\right)$, \\
class V - heavily to extremely contaminated $\left(4.0<\mathrm{I}_{\text {geo }}<5.0\right)$, \\
class VI - extremely contaminated $\left(\mathrm{I}_{\text {geo }}>5.0\right)$.
\end{tabular}


background appears to yield a more representative assessment. This radically alters our quality assessment of sediments in anthropogenic water bodies in the Silesian Upland. In three cases, these exhibit extreme $\mathrm{Cd}$ contamination; water bodies with uncontaminated or moderately contaminated sediments clearly dominate, plus there is also an intermediate number of water bodies with heavily contaminated sediments.

\section{Conclusions}

1. Concentrations of $\mathrm{Cd}$ in the bottom sediments of the water bodies examined range from 0.7 to $580.0 \mathrm{mg} \mathrm{kg}^{-1}$. These values are higher than the natural range of concentrations for this element in the Earth's crust $\left(0.1-0.3 \mathrm{mg} \mathrm{kg}^{-1}\right)$ and the geochemical background for Poland $\left(0.5 \mathrm{mg} \mathrm{kg}^{-1}\right)$ and, with a few exceptions, was also higher than the preindustrial concentration $\left(1.0 \mathrm{mg} \mathrm{kg}^{-1}\right)$ and the regional geochemical background $\left(2.5 \mathrm{mg} \mathrm{kg}^{-1}\right)$. They are also so high that no comparable levels can be found anywhere else in the world.

2. The quality of bottom sediments of the water bodies studied may be given different classifications depending on the geochemical background adopted for $\mathrm{Cd}$. When natural $\mathrm{Cd}$ concentrations in the Earth's crust are adopted as the baseline, the sediments can be classified as extremely and heavily contaminated (and moderately contaminated in a small number of cases). The assessment of sediment quality based on the regional geochemical background results in the domination of non-contaminated and moderately contaminated sediments with a far smaller share of heavily and extremely contaminated sediments.

3. The geoaccumulation index as an indicator of the quality of bottom sediments is a measure that requires proper interpretation, especially when different geochemical background levels are used for determining its value.

4. The presence of $\mathrm{Cd}$ in the bottom sediments of water bodies (especially at levels exceeding the geochemical background) is a good indicator of the geoecological condition of the environment and the potential problems related to the natural functioning and economic use of such water bodies.

Acknowledgments I would like to thank the editors and referees for their kind comments and constructive criticism of my article as well as my colleagues from the Department of Physical Geography, Faculty of Earth Sciences, University of Silesia for their help in the research conducted. I would also like to thank the linguistic team-translator Bartłomiej Pietrzyk, MA, MEng and native English proof-reader Martin Cahn, Ph.D - for the linguistic corrections of the manuscript.

Open Access This article is distributed under the terms of the Creative Commons Attribution 4.0 International License (http:// creativecommons.org/licenses/by/4.0/), which permits unrestricted use, distribution, and reproduction in any medium, provided you give appropriate credit to the original author(s) and the source, provide a link to the Creative Commons license, and indicate if changes were made.

\section{References}

Alikaj M, Brahushi FI, Rada Z (2014) Heavy metals contamination of the sediments in the Viroi Lake of Gjirokastra District Albania. Thalassia Sal 36:35-42

Astrom M, Nylund K (2000) Impact of historical metalworks on the concentrations of major and trace elements in sediments: a case study in Finland. Appl Geochem 15:807-817

Attia OEA, Ghrefat H (2013) Assessing heavy metal pollution in the recent bottom sediments of Mabahiss Bay, North Hurghada, Red Sea, Egypt. Environ Monit Assess 185:9925-9934

Bai J, Xiao R, Zhang K, Gao H (2012) Arsenic and heavy metal pollution in wetland soils from tidal freshwater and salt marshes before and after the flow-sediment regulation regime in the Yellow River Delta, China. J Hydrol 450-451:244-253

Bąk Ł, Gorski J, Rabajczyk A, Szwed M (2013) Content of heavy metal compounds in the bottom sediments of the Suchedniów water reservoir. Proceedings of ECOpole 7:287-294

Bennet-Chambers M, Davies P, Knott B (1999) Cadmium in aquatic ecosystems in Western Australia: a legacy of nutrient-deficient soils. J Environ Manage 57:283-295

Bing H, Wul Y, Sun Z, Yao S (2011) Historical trends of heavy metal contamination and their sources in lacustrine sediment from Xijiu Lake, Taihu Lake Catchment, China. J Environ Sci 23:1671-1678

Bojakowska I, Sokołowska G (1998) Geochemical classes of purity of water deposits [in Polish]. Polish Geol Rev 46:49-54

Bowen HJM (1966) Trace elements in biochemistry. Academic Press, London, UK

Cáceres Choque LF, Ramos Ramos OE, Valdez Castro SN, Choque Aspiazu RR, Choque Mamani RG, Fernández Alcazar SG, Sracek O, Bhattacharya P (2013) Fractionation of heavy metals and assessment of contamination of the sediments of Lake Titicaca. Environ Monit Assess 185:9979-9994

Chen CA, Wu J, Wang B, Huang K (2004) Acidification and trace metals of lakes in Taiwan. Aquatic Geochem 10:33-57

Choiński A, Diatta JB, Lawniczak AE (2010) Assessment of Cu, Zn, Pb and Cd contamination of bottom sediments in Lake Niepruszewskie. In: Ciupa T, Suligowski R (eds) Water in geographical research. Jan Kochanowski University, Kielce, Poland, pp 159-167 (in Polish with English summary)

Ciszewski D, Pociask-Karteczka J, Żelazny M (1998) Heavy metals in bottom sediments of artificial water reservoirs in Cracow Area. Polish J Environ Stud 7:71-73

Ciszewski D, Aleksander-Kwaterczak U, Pociecha A, Szarek-Gwiazda E, Waloszek A, Wilk-Wozniak E (2013) Small effects of a large sediment contamination with heavy metals on aquatic organisms in the vicinity of an abandoned lead and zinc mine. Environ Monit Assess 185:9825-9842

El-Sayed SA, Moussa EMM, El-Sabagh MEI (2015) Evaluation of heavy metal content in Qaroun Lake, El-Fayoum, Egypt. Part I: bottom sediments. J Radiat Res Appl Sci 8:276-285

Fajer M, Waga JM, Rzetala M, Szymczyk A, Nita M, Machowski R, Rzetala MA, Ruman M (2012) The Late Vistulian and Holocene evolution of Jezioro Lake: a record of environmental change in southern Poland found in deposits and landforms. J Paleolimnol 48:651-667

Förstner U, Müller G (1981) Concentrations of heavy metals and polycyclic aromatic hydrocarbons in river sediments: geochemical background, man's influence and environmental impact. GeoJournal 5: $417-432$

Gao F, Wang J, Guo W, Zhao X (2015) Historical record of trace elements input and risk in the shallow freshwater lake, North China. J Geochem Explor 155:26-32 
Ghrefat H, Yusuf N (2006) Assessing Mn, Fe, Cu, Zn, and Cd pollution in bottom sediments of Wadi Al-Arab Dam, Jordan. Chemosphere 65: 2114-2121

Goher ME, Farhat HI, Abdo MH, Salem SG (2014) Metal pollution assessment in the surface sediment of Lake Nasser, Egypt. Egyptian J Aquat Res 40:213-224

Guo W, Huo S, Xi B, Zhang J, Wu F (2015) Heavy metal contamination in sediments from typical lakes in the five geographic regions of China: distribution, bioavailability, and risk. Ecol Eng 81:243-255

Håkanson L (1980) An ecological risk index for aquatic pollution control. A sedimentological approach. Water Res 14:975-1001

$\mathrm{Hu}$ X, Wang C, Zou L (2011) Characteristics of heavy metals and Pb isotopic signatures in sediment cores collected from typical urban shallow lakes in Nanjing, China. J Environ Manage 92:742-748

Jankowski AT, Molenda T, Rzętała MA, Rzętała M (2002) Heavy metals in bottom deposits of artificial water reservoirs of the Silesian Upland an as indicator of human impact into the environment. Limnol Rev 2:171-180

Kabata-Pendias A, Pendias H (1979) Trace elements in a biological environment. Geological Publishing, Warsaw

Kabata-Pendias A, Pendias H (1993) Biogeochemistry of trace elements. PWN, Warsaw

Kabir I, Lee H, Kim G, Jun T (2011) Correlation assessment and monitoring of the potential pollutants in the surface sediments of Pyeongchang River, Korea. Int J Sediment Res 26:152-162

Kalender L, Uçar SC (2013) Assessment of metal contamination in sediments in the tributaries of the Euphrates River, using pollution indices and the determination of the pollution source, Turkey. J Geochem Explor 134:73-84

Kankilic GB, Tuzun I, Kadioglu YK (2013) Assessment of heavy metal levels in sediment samples of Kapulukaya Dam Lake (Kirikkale) and lower catchment area. Environ Monit Assess 185:6739-6750

Klavinš M, Briede A, Klavina I, Rodinov V (1995) Metals in sediments of lakes in Latvia. Environ Int 21:451-458

Li YH (2000) A compendium of geochemistry: from solar nebula to the human brain. Princeton University Press, Princeton, NJ, USA

Li YH, Schoonmaker JE (2005) Chemical composition and mineralogy of marine sediments. In: Mackenzie FT, Holland HD, Turekian KK (eds) Sediments, diagenesis, and sedimentary rocks 7. Treatise on Geochemistry. Elsevier, Amsterdam, The Netherlands, pp 1-35

Lis J, Pasieczna A (1995a) Geochemical Atlas of Poland, 1:2500000. Polish Geological Institute, Warsaw, Poland

Lis J, Pasieczna A (1995b) Geochemical Atlas of Upper Silesia, 1: 200000. Polish Geological Institute, Warsaw, Poland

Lopez DL, Gierlowski-Kordesch E, Hollenkamp C (2010) Geochemical mobility and bioavailability of heavy metals in a lake affected by acid mine drainage: Lake Hope, Vinton County, Ohio. Water Air Soil Pollut 213:27-45

Loska K, Wiechuła D (2003) Application of principal component analysis for the estimation of source of heavy metal contamination in surface sediments from the Rybnik Reservoir. Chemosphere 51: 723-733

Moalla SMN, Awadallah RM, Rashed MN, Soltan ME (1998) Distribution and chemical fractionation of some heavy metals in bottom sediments of Lake Nasser. Hydrobiologia 364:31-40

Molenda T (2001) Heavy metals in bottom deposits of anthropogenic water reservoirs in Katowice. Limnol Rev 1:213-218

Müller G (1979) Schwermetalle in den sedimenten des rheinsveränderungen seit 1971. Umschau in Wissenschaft und Technik 79:778-783

Müller G (1986) Schadstoffe in sedimenten - sedimente als schadstoffe. Umweltgeologie Band 79:107-126

Newell AD, Skjelkvale BL (1997) Acidification trends in surface waters in the International Program on Acidification of Rivers and Lakes. Water Air Soil Pollut 93:27-57
Nguyen HL, Leermakers M, Osán J, Török S, Baeyens W (2005) Heavy metals in Lake Balaton: water column, suspended matter, sediment and biota. Sci Total Environ 340:213-230

Nikolaidis C, Zafiriadis I, Mathioudakis V, Constantinidis T (2010) Heavy metal pollution associated with an abandoned lead-zinc mine in the Kirki Region, NE Greece. Bull Environ Contam Toxicol 85: 307-312

Olmedo P, Pla A, Hernández AF, Barbier F, Ayouni L, Gil F (2013) Determination of toxic elements (mercury, cadmium, lead, tin and arsenic) in fish and shellfish samples. Risk assessment for the consumers. Environ Int 59:63-72

O'Neill A, Phillips DH, Bowen J, Sen Gupta B (2015) Contaminants in surface water and sediments near the Tynagh silver mine site, County Galway, Ireland. Sci Total Environ 512-513:261-272

Ong MC, Menier D, Shazili NAM, Kamaruzzaman BY (2013) Geochemical characteristics of heavy metals concentration in sediments of Quiberon Bay waters, South Brittany, France. Oriental J Chem 29:39-45

Özkan EY (2012) A new assessment of heavy metal contaminations in a eutrophicated bay (Inner Izmir Bay, Turkey). Turk J Fish Aquat Sci 12:135-147

Palma P, Ledo L, Alvarenga P (2015) Assessment of trace element pollution and its environmental risk to freshwater sediments influenced by anthropogenic contributions: the case study of Alqueva reservoir (Guadiana Basin). Catena 128:174-184

PGI (2006) Geological Map of Poland, 1:500,000. Ministry of the Environment, Polish Geological Institute (PGI) - National Research Institute, Warsaw, Poland

Pradit S, Wattayakorn G, Angsupanich S, Leemaker M, Baeyens W (2010) Distribution of trace elements in sediments and biota of Songkhla Lake, southern Thailand. Water Air Soil Pollut 206:155174

Pradit S, Pattarathomronga MS, Panutrakulb S (2013) Arsenic, cadmium and lead concentrations in sediment and biota from Songkhla Lake: a review. Procedia_-Social Behavioral Sci 91:573-580

Rabee AM, Al-Fatlawy YF, Abdown AN, Nameer M (2011) Using pollution load index (PLI) and geoaccumulation index (I-Geo) for the assessment of heavy metals pollution in Tigris River sediment in Baghdad region. J Al-Nahrain Uni 14:108-114

Rognerud S, Hongve D, Fjeld E, Ottesen RT (2000) Trace metal concentrations in lake and overbank sediments in southern Norway. Environ Geol 39:723-732

Rubin H, Rubin K, Siodłak A, Skuza P (2011) Assessment of contamination of the bottom sediments of the Stoła river with selected metals and metalloids within the urban-industrial area of Tarnowskie Góry [in Polish with English summary]. Biuletyn Państwowego Instytutu Geologicznego 445:615-624

Rzętała MA (2014) Selected geomorphological transformations of water body basins and an assessment of bottom sediment pollution under different levels of human pressure (as exemplified by the Upper Silesia and Dąbrowa Basin region). University of Silesia, Katowice

Rzetała MA (2015a) Lead in the bottom sediments of water bodies in the Upper Silesia region (southern Poland). Desalination and Water Treatment 54:779-789

Rzetała MA (2015b) Assessment of toxic metal contamination of bottom sediments in water bodies in urban areas. Soil Sediment Contam 24: 49-63

Rzętała MA (2015c) Basic components and trace elements in sediments in the inactive channel of the Dunajec River (Pieniny Mts.) and their geo-ecological significance. Carpath J Earth Env 10:85-94

Rzętała M, Jaguś A (2012) New lake district in Europe: origin and hydrochemical characteristics. Water Environ J 26:108-117

Rzetala MA, Jagus A, Machowski R, Rzetala M (2015) The development of freshwater deltas and their environmental and economic significance. Ecol Chem Engineer S 22:107-123 
Rzętała M, Jaguś A, Rzetała MA, Rahmonov O, Rahmonov G, Khak V (2013) Variations in the chemical composition of bottom deposits in anthropogenic lakes. Pol J Environ Stud 22:1799-1805

Saleem M, Iqbal J, Shah MH (2012) Study of seasonal variations and risk assessment of selected metals in sediments from Mangla Lake, Pakistan. J Geochem Explor 125:144-152

Selvam AP, Priya SL, Banerjee K, Hariharan G, Purvaja R, Ramesh R (2013) Heavy metal assessment using geochemical and statistical tools in the surface sediments of Vembanad Lake Southwest Coast of India. Environ Monit Assess 184:5899-5915

Sienkiewicz E, Gąsiorowski M, Hercman H (2006) Is acid rain impacting the Sudetic lakes? Sci Total Environ 369:139-149

Stuchlik E, Kopacek J, Fott J, Horicka Z (2006) Chemical composition of the Tatra Mountain lakes: response to acidification. Biologia 61:1120

Świderska-Bróż M (1993) Micropollutants in the aquatic environment [in Polish]. University of Technology, Wrocław, Poland

Szymczyk A (2012) Relations between assemblages of carpological remains and modern vegetation in a shallow reservoir in southern Poland. J Paleolimnology 48:503-516

Tang Q, Bao Y, He X, Zhou H, Cao Z, Gao P, Zhong R, Hu Y, Zhang X (2014) Sedimentation and associated trace metal enrichment in the riparian zone of the Three Gorges Reservoir, China. Sci Total Environ 479-480:258-266

Tao Y, Yuan Z, Wei M, Xiaona H (2012) Characterization of heavy metals in water and sediments in Taihu Lake, China. Environ Monit Assess 184:4367-4382

Taylor SR (1964) Abundances of chemical elements in the continental crust: a new table. Geochim Cosmochim Acta 28:1273-1285

Taylor SR, McLennan SM (1995) The geochemical evolution of the continental crust. Rev Geophysics 33:241-265

Turekian KK, Wedepohl KH (1961) Distribution of the elements in some major units of the Earth's crust. Geol Soc Am Bull 72:175-192
Tylmann W (2004) Heavy metals in recent lake sediments as an indicator of 20th century pollution: Case study on lake Jasień. Limnological Rev 4:261-268

Tylmann W, Lysek K, Kinder M, Pempkowiak J (2011) Regional pattern of heavy metal content in lake sediments in Northern Poland. Water Air Soil Pollut 216:217-228

Varol M, Sen B (2012) Assessment of nutrient and heavy metal contamination in surface water and sediments of the upper Tigris River, Turkey. Catena 92:1-10

Vrhovnik P, Smuc NR, Dolenec T, Serafimovski T, Dolenec M (2013) An evaluation of trace metal distribution and environmental risk in sediments from the Lake Kalimanci (FYR Macedonia). Environ Earth Sci 70:761-775

Wang L-F, Yang L-Y, Kong L-H, Li S, Zhu J-R, Wang Y-Q (2014) Spatial distribution, source identification and pollution assessment of metal content in the surface sediments of Nansi Lake, China. J Geochem Explor 140:87-95

www.actlabs.com (2016) Accessed 20 January 2016

Yahaya MI, Jacob AG, Agbendeh ZM, Akpan GP, Kwasara AA (2012) Seasonal potential toxic metals contents of Yauri river bottom sediments: north western Nigeria. J Environ Chem Ecotoxicol 4:212221

Young SM, Ishiga H, Pitawala A (2012) Geochemical assessment of Upper Mahaweli River and Polgolla Reservoir sediments, Sri Lanka. APCBEE Procedia 1:53-58

Zeng H-A, Wu J-L (2009) Sedimentary records of heavy metal pollution in Fuxian Lake, Yunnan Province, China: intensity, history, and sources. Pedosphere 19:562-569

Zeng J, Yang LY, Chuai XM, Chen XF, Zhao HY, Wu QL (2013) Comparison of metal(loid) concentrations in water, sediments and fish from two large shallow lakes. Int J Environ Sci Technol 10: 1209-1218 